\title{
Seeing the light: depth and time restrictions in the foraging capacity of emperor penguins at Pointe Géologie, Antarctica
}

\author{
Ilka Zimmer ${ }^{1, *}$, Rory P. Wilson $^{2}$, Michaël Beaulieu ${ }^{3}$, André Ancel $^{3}$, Joachim Plötz ${ }^{1}$ \\ ${ }^{1}$ Alfred Wegener Institute for Polar and Marine Research, PO Box 120161, 27515 Bremerhaven, Germany \\ ${ }^{2}$ Institute of Environmental Sustainability, School of Biological Sciences, University of Wales Swansea, Singleton Park, \\ Swansea SA2 8PP, Wales, UK \\ ${ }^{3}$ IPHC —Département Écologie, Physiologie et Éthologie - UMR7178 Centre National de la Recherche Scientifique and \\ Université Louis Pasteur, 23 rue Becquerel, 67087 Strasbourg, France
}

\begin{abstract}
The foraging ability of visual hunters depends critically on light conditions. Emperor penguins Aptenodytes forsteri are reported to be visual hunters, but breed and forage at high latitudes and are thus exposed to extreme changes in light conditions in the course of the year. We examined how light influenced the foraging ability of breeding emperor penguins using loggers in winter $(n=5)$ and spring (n = 4) 2005 at Pointe Géologie $\left(66^{\circ} 40^{\prime} \mathrm{S}, 140^{\circ} 01^{\prime} \mathrm{E}\right)$, Antarctica, as well as by using models of light availability over the year and as a function of depth. The model showed that daylight was continuous between days of the year 350 and 363 and that the sun did not rise between days of the year 166 and 180. Logger-measured light intensity decreased with water depth, and depth-specific values were higher at greater sun elevation angles. Depth-time use (given by the maximum depth reached multiplied by the number of hours at which this depth could be achieved over $24 \mathrm{~h}$ ) of spring-foraging penguins was $8394.5 \mathrm{~m} \times \mathrm{h}$, which was more than twice that of winter-foraging birds at $3845.4 \mathrm{~m} \times \mathrm{h}$, showing the severe constraints imposed by winter conditions. Average catch-per-unit effort was related to mean maximum diving depth and was highest around mid-day in winter and highest during dawn and dusk in spring. This reflects availability of prey to foraging emperor penguins.
\end{abstract}

KEY WORDS: Light intensity $\cdot$ Foraging $\cdot$ Emperor penguins $\cdot$ Depth-time availability Resale or republication not permitted without written consent of the publisher

\section{INTRODUCTION}

The ability of marine animals to forage is often constrained by the physical characteristics of the environment. For example, temperature (reptiles, e.g. Vitousek et al. 2007), depth (whales, e.g. Thode et al. 2002) and light (visual hunters, e.g. Wanless et al. 1999) enhance or compromise foraging ability. Although penguins are considered to be restricted in the maximum depth they can achieve for physiological reasons (Williams 1995), light has also been cited as being important (Wilson et al. 1989, 1993, Pütz \& Bost 1994, Kooyman \& Kooyman 1995, Kirkwood \& Robertson 1997a, Wienecke \& Robertson 1997, Cannell \& Cullen 1998, Peters et al. 1998, Pütz et al. 1998,
Luna-Jorquera \& Culik 1999, Bost et al. 2002) since these birds are reputed to hunt by vision. Indeed, there are a number of studies that appear to show that the maximum dive depth achieved by penguins in the wild is often limited by the availability of light (e.g. Wilson et al. 1993, Pütz \& Bost 1994, Cannell \& Cullen 1998, Ropert-Coudert et al. 2006). Emperor penguins Aptenodytes forsteri are the deepest diving of all penguin species, an ability that has been linked to their large size (Ponganis \& Kooyman 2000, Halsey et al. 2006). If these birds are indeed limited in the depths that they can exploit by light, it seems strange that they, coincidently, are the largest penguin species and forage under exceptional conditions of light. Perhaps, however, it is the exceptional lighting condi- 
tions, illuminating greater depths down the water column, that tended to select for larger sized penguins, because these penguins can dive deep. In fact, emperor penguins belong to the most southerly breeding birds (to $78^{\circ} \mathrm{S}$; Woehler 1993) and forage in exceptionally clear waters (Jerlov 1968), in areas of light that vary from continuous daylight (with the sun above the horizon) to just a few dimlight hours (without the sun above the horizon) per $24 \mathrm{~h}$ cycle (Iqbal 1983).

Data in the literature suggest that emperor penguins are indeed visual hunters seeing their prey items by shadow theatre and that their activity patterns, particularly as related to foraging, are closely linked with the light/dark cycle (Wilson et al. 1989, Kooyman \& Kooyman 1995, Kirkwood \& Robertson 1997b, Wienecke \& Robertson 1997).

This study focuses on the potential of light in modulating the foraging ability of emperor penguins. We examined the diurnal foraging activity of emperor penguins in winter and spring and analysed the light intensity over a whole year at Terre Adélie, Antarctica, in order to estimate the maximum depth availability over the breeding cycle. We consider the implications that this has for a species that breeds and forages at high latitude year-round, and is thus exposed to extremes in light availability.

\section{MATERIALS AND METHODS}

Dive patterns of emperor penguins Aptenodytes forsteri were examined for 9 emperor penguins during winter ( $\mathrm{n}=5)$ and spring $(\mathrm{n}=4) 2005$ at Pointe Géologie, Terre Adélie $\left(66^{\circ} 40^{\prime} \mathrm{S}, 140^{\circ} 01^{\prime} \mathrm{E}\right)$. In winter, 3 females and 2 males were fitted with time-depth recorders (Mk9, Wildlife Computers, $67 \times 17 \times 17 \mathrm{~mm}$, $30 \mathrm{~g}$ ) and with satellite transmitters (Sirtrack, $130 \times 50$ $\times 30 \mathrm{~mm}, 230 \mathrm{~g}$ ), while they were conducting foraging trips between 22 May and 29 August. In spring, 4 further birds were deployed with an archival data satellite transmitter (Splash, Wildlife Computers, $78 \times 50 \times$ $23 \mathrm{~mm}, 105 \mathrm{~g}$ ), recording foraging patterns between 2 and 21 November. Devices were fixed to the lower back feathers of penguins so as to minimize hydrodynamic drag (Bannasch et al. 1994) using tape (Wilson et al. 1997). Dive depth and light intensity were recorded at intervals of $5 \mathrm{~s}$ in winter and of $2 \mathrm{~s}$ (depth) and $10 \mathrm{~s}$ (light) in spring. Devices provided a depth range of 0 to $1000 \mathrm{~m}$. Light sensors were pre-calibrated by Wildlife Computers, and light-level data (dimensionless) ranged from $\sim 50$ (when the light sensor was covered in a 'bright room') to 180 (a 'bright room'). Foraging distribution and satellite positions have been published elsewhere (see Zimmer et al. 2007b) and will not be further described in this context. Units were recovered after birds had been absent at sea for 1 or 2 foraging trips.

Measures for absolute solar irradiation $\left(\mathrm{W} \mathrm{m}^{-2}\right)$ and sun angle $\left({ }^{\circ}\right.$ ) were processed for Pointe Géologie over the year 2005 based on calculations given by Iqbal (1983). As a measure for light intensity, at the water surface, global radiation was used (Fig. 1a), which is lower than the absolute solar irradiation due to extinction processes. From the Antarctic wintering station Neumayer, it is known that global radiation, typically varies between 40 and $80 \%$ of absolute solar irradiation, depending mostly on clouds and surface albedo (König-Langlo \& Loose 2007). Since we were unable to make any in situ global radiation measurements, we took $50 \%$ of the absolute solar irradiation as the best approximation of light conditions on site. Consequently, the relative global radiation was estimated here after correcting for cloud cover by dividing the absolute irradiation by 2 . The variance in impinging light noted above indicates the extent to which our approximations derived from models may vary from the real values. This should not, however, detract from showing trends, which is the purpose of this exercise.

Light availability underwater is a function of time of day and water depth, and the ability to perceive prey for a visual predator can be defined by a critical light intensity that represents the lowest illumination at which prey can be perceived (Wilson et al. 1989). Theoretical changes in depth utilization over time by foraging emperor penguins (Fig. 2) were estimated by the following equation:

$$
\text { Light }_{\text {available }}=\text { Light }_{\text {Intensity }} \times \operatorname{Exp}\left(-\mathrm{C}_{\omega} \times \text { Depth }\right)
$$

where 'Light intensity' is the relative global radiation (after correcting for some cloud cover, $\mathrm{W} \mathrm{m}^{-2}$ ) and $c_{\omega}$ is the attenuation coefficient of 0.01 used for 'nonproductive seawater' (Type 1; very good light transmission) taken from Jerlov (1968) (Fig. 1b). This calculation for available light at depth is optimistic, since we assumed a water body of exceptional clarity. Derived values are intended to elucidate general trends, which may differ in magnitude according to environmental factors, e.g. sea-ice and weather conditions (not examined in our study). We note also that we were unable to determine the effective sensitivity of the penguin eye to prey in the wild (cf. Martin \& Young 1984, Sivak et al. 1987, Martin 1999). We derived a 'depth-time availability index' (DTAI) for each day of the year by assuming that emperor penguins need a critical light intensity of at least $30 \mathrm{~W} \mathrm{~m}^{-2}$ in order to perceive prey (a value derived by looking at maximum dive depths over time in relation to modelled light availability - see above). We note that it is appropriate to use some critical value for visual threshold and that different values 

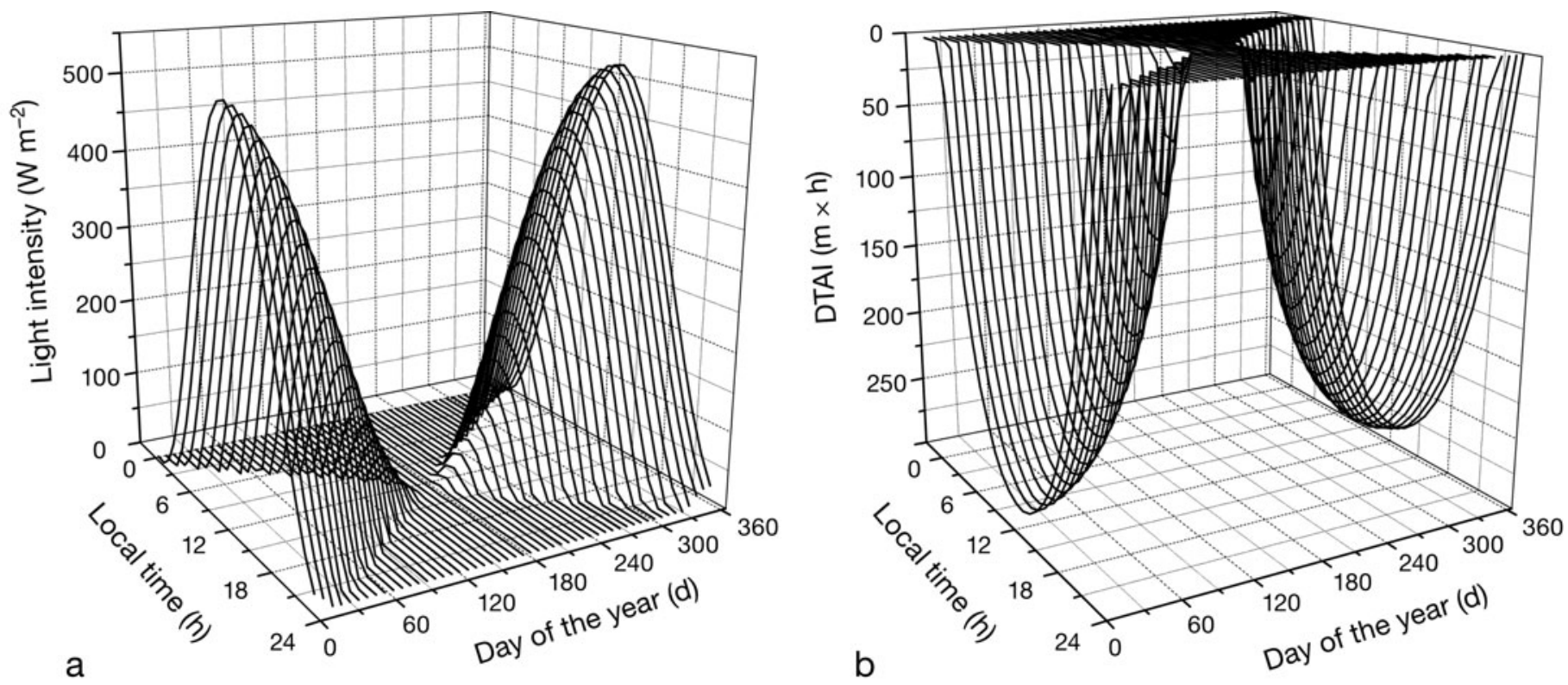

Fig. 1. (a) Light intensity (global radiation estimated through cloud cover in $\mathrm{W} \mathrm{m}^{-2}$ ) and (b) depth-time availability index (DTAI, $\mathrm{m} \times \mathrm{h}$ ), derived by an assumed critical light intensity of $30 \mathrm{~W} \mathrm{~m}^{-2}$, representing the lowest illumination at which prey can be perceived, for local time of the day in 2005 in Terre Adélie, Antarctica $\left(66^{\circ} 40^{\prime} \mathrm{S}, 140^{\circ} 01^{\prime} \mathrm{E}\right)$. Parameters were calculated weekly according to Eq. (1)

for this threshold will change absolute values of the depths to which emperor penguins could/should dive. However, different values of the threshold will not change the general form of seasonally apparent trends in volumes of water available to emperor penguins, and it is this that our manuscript seeks to highlight.

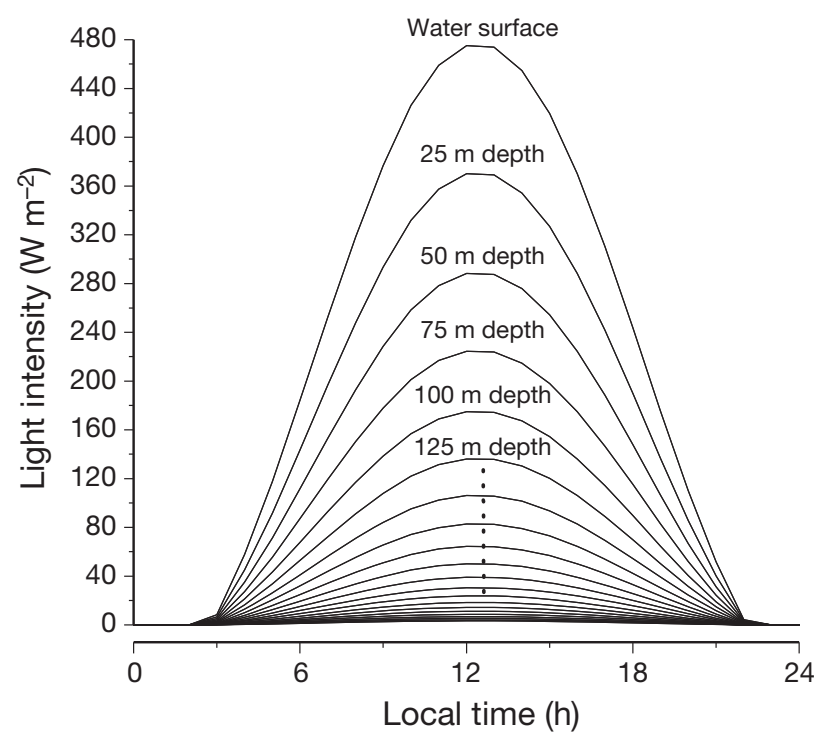

Fig. 2. Light intensity $\left(\mathrm{W} \mathrm{m}^{-2}\right)$ for different water depths for local time on day of the year 324 in 2005 in Terre Adélie, Antarctica $\left(66^{\circ} 40^{\prime} \mathrm{S}, 140^{\circ} 01^{\prime} \mathrm{E}\right)$, estimated according to Eq. (1)
DTAI values integrated the depths over which penguins could see prey (where light intensity $>30 \mathrm{~W} \mathrm{~m}^{-2}$ ) over each full day and had units of metres $\times$ hours $(\mathrm{m} \times \mathrm{h})$.

To examine the foraging activity of penguins in relation to the time of day recorded, depth data were analysed by using special software (MT-dive; Jensen Software). All dives $>2 \mathrm{~m}$ were analysed sequentially for the following parameters: time of dive initiation; overall dive duration; maximum depth reached during the dive; descent-, bottom- and ascent-phase durations; vertical velocities during the descent, bottom and ascent phases; number serial points of inflection (SPI) during the bottom phase; and post-dive interval. For specific details of this analysis see Zimmer et al. (2007b). As an attempt to derive a catch-per-unit effort (CPUE) index, a measure of prey pursuit, we divided the number of SPIs identified during the bottom phase of all dives by the respective bottom dive duration. Although the SPI estimates do not provide absolute prey abundance indices, we consider an approximate linear relationship to prey caught, so that CPUE values $\left(\mathrm{SPI} \mathrm{min}^{-1}\right.$ ) should relate to the extent of prey pursuit (cf. Kirkwood \& Robertson 1997b, Luna-Jorquera \& Culik 1999, Hull 2000, Rodary et al. 2000b, Tremblay \& Cherel 2000, Takahashi et al. 2004, Zimmer et al. 2007b). The diving efficiency (DE, dimensionless) was calculated following the equation of Ydenberg \& Clark (1989): 


$$
\mathrm{DE}=\frac{\text { bottom duration }}{(\text { dive duration }+ \text { post-dive duration })}
$$

being expressed as a non-dimensional fraction.

Measured light intensity at depth for different sun angles, maximum dive depth, CPUE and DE over the day were examined per individual before being converted to grand means, in order to correct for sample size biases. Grand means are presented $( \pm \mathrm{SE})$, if not explained differently and were averaged per $25 \mathrm{~m}$ maximum dive depth interval or per hour of the day. Light intensity was analysed for all dives $>2 \mathrm{~m}$. The 3 latter dive parameters were calculated for dives with post-dive durations of $<25$ min (this being delineated by a point of inflection in the frequency of the postdive duration graph, cf. bout-ending criterion; Gentry \& Kooyman 1986) and the occurrence of a bottom dive phase. Throughout the present study, time is expressed as local time, i.e. UTC $+10 \mathrm{~h}$. Days of the year are each considered to commence at $0 \mathrm{~h}$. The correlation of parameters was examined using simple linear regressions. Data were normally distributed and tested for significance by a parametric 1-way ANOVA $(F)$. Significance of the results was judged at the 0.05 level. Data were processed using Excel, Origin 7.5 and SigmaStat 3.5 software packages.

\section{RESULTS}

At Pointe Géologie, Terre Adélie, the solar radiation was highest during the Antarctic summer on day of the year 358, with a maximum global irradiation (estimated for mean cloud cover) of $514.5 \mathrm{~W} \mathrm{~m}^{-2}$ during a period of continuous daylight between days of the year 350 and 363 in 2005 (Fig. 1a). Light intensity and daylight hours declined over autumn, reaching a minimum dark period of $0 \mathrm{~W} \mathrm{~m}^{-2}$ at any hour of the day in the Antarctic winter between days of the year 166 and 180. The estimated DTAI showed the extent to which light availability over the course of a year, coupled with attenuation in the water column, might compromise penguin foraging capacity (Fig. 1b). DTAI for foraging penguins is highest in summer, when daylight is maximal, and lowest in winter, when light availability is lowest.

Light intensity as recorded by devices from 4 emperor penguins during foraging in spring decreased with increasing water depth until the minimum value of 56.7 arbitrary units, recorded for a single dive (Fig. 3). This trend was apparent at all times of the day, although light intensity was higher at greater sun elevation angles up to certain depths (Fig. 3).

The diving patterns of the penguins equipped in winter $(n=5)$ and spring $(n=4)$ showed marked sea- sonality, with the trend closely following the increase in availability of ambient light between the 2 seasons (Fig. 4). During winter, between 22 May and 29 August 2005, penguins only dived between 07:00 and 19:00 h, with $78 \%$ of all dives conducted between 10:00 and 15:00 h (Fig. 4a,c). Dives were deepest when light was most intense (Fig. 4a). In spring, between 2 and 21 November 2005, with almost continuous daylight, penguins dived at any hour of the day (Fig. 4b,d to depths of up to $200 \mathrm{~m}$ ), although dives deeper than $350 \mathrm{~m}$ only occurred during periods of peak light intensity, between 05:42 and 18:03 h. Maximum depths were reached between 12:00 and 13:00 $\mathrm{h}$, and the highest rate of dives occurred from 07:00 to 08:00 h. In springforaging penguins, the overall utilisation of the water column to maximum dive depth over the $24 \mathrm{~h}$ cycle (DTAI) was more than twice that of winter-foraging penguins (8394.5 vs. $3845.4 \mathrm{~m} \times$ h, respectively; Fig. 5). The estimated DTAI over the yearly cycle in 2005 showed minima and maxima during winter and summer, respectively (Fig. 6), which roughly corresponded to the trends observed in wild penguins. We do not expect absolute values to concur here due to our inability to determine proper thresholds for visual acuity in penguins (see above).

Since maximum depth varies over the diel cycle, it is not very surprising to find that mean dive depth also varies systematically and in a comparable manner (Fig. 7). Dive efficiency showed a trend that was the inverse of this (winter: $\mathrm{r}^{2}=0.4, F=30.09$; $\mathrm{p}<0.0001$; spring: $\mathrm{r}^{2}=1.26 \times 10^{-4}, F=0.01, \mathrm{p}=0.92$; Fig. 8). CPUE during winter was maximal at mid-day, dipping

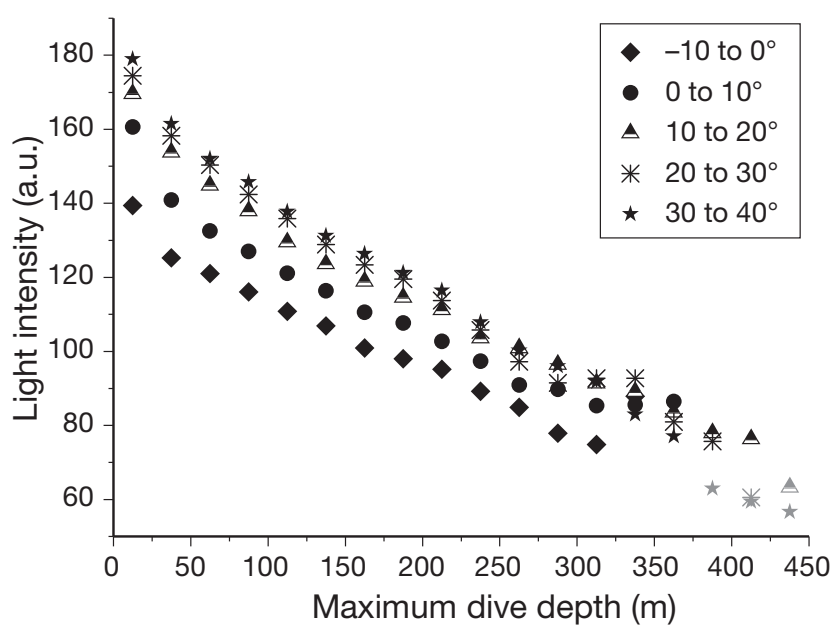

Fig. 3. Light intensity (arbitrary units, a.u.) for different sun angles showing the attenuation of light with maximum dive depth. Values are grand mean light records from mean values of 4 penguins studied between 2 and 21 November 2005 at Pointe Géologie, Terre Adélie. Grey symbols show single records 

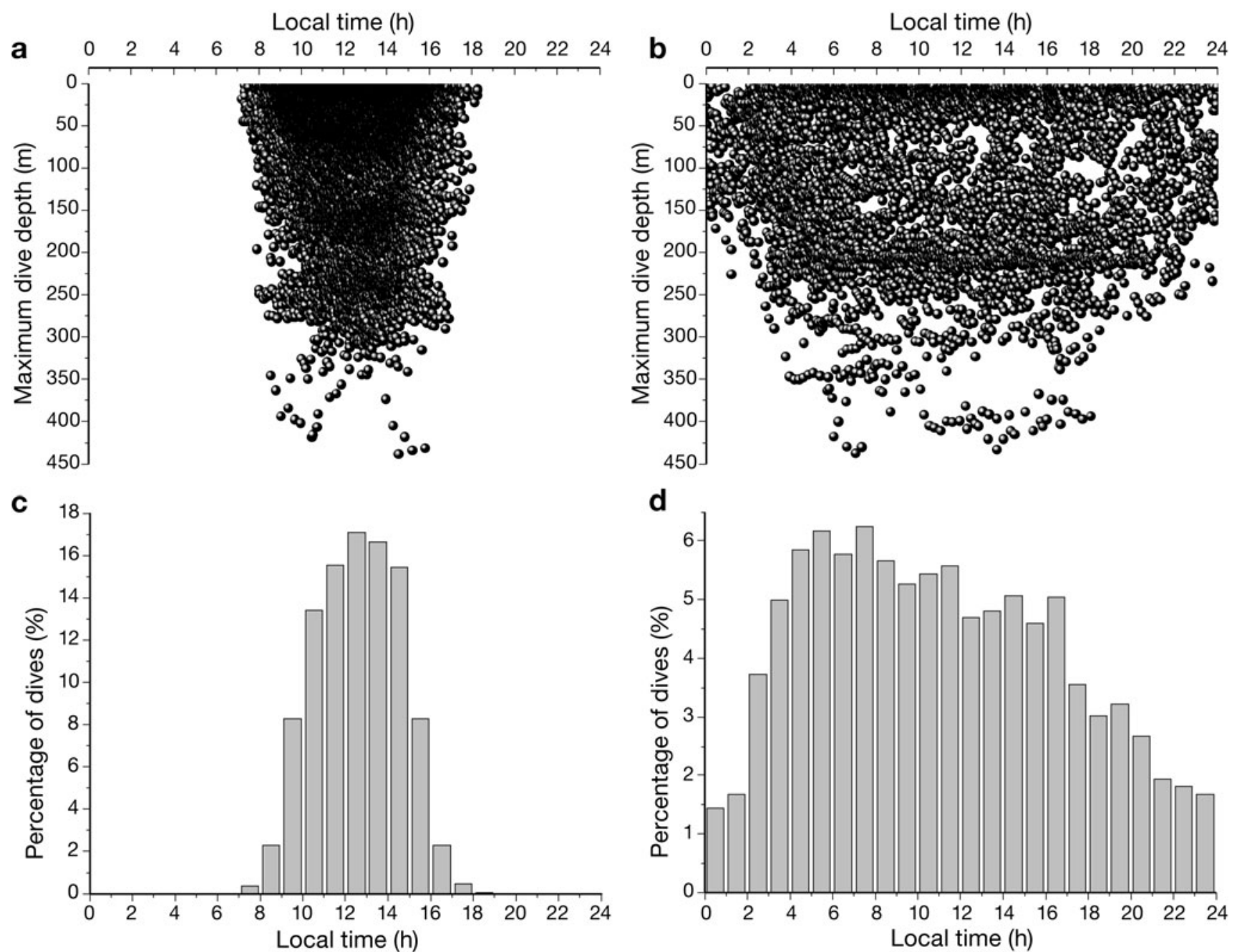

Fig. 4. Aptenodytes forsteri. Maximum dive depth $(\mathrm{a}, \mathrm{b})$ and frequency distribution of the number of dives (c,d) as a function of time of day for dives $>2 \mathrm{~m}$ conducted by: $(\mathrm{a}, \mathrm{c}) 5$ penguins in winter, between 22 May and 29 August 2005 (n = 19077 dives), and (b,d) 4 penguins in spring, between 2 and 21 November 2005 ( $\mathrm{n}=5467$ dives), at Pointe Géologie, Terre Adélie

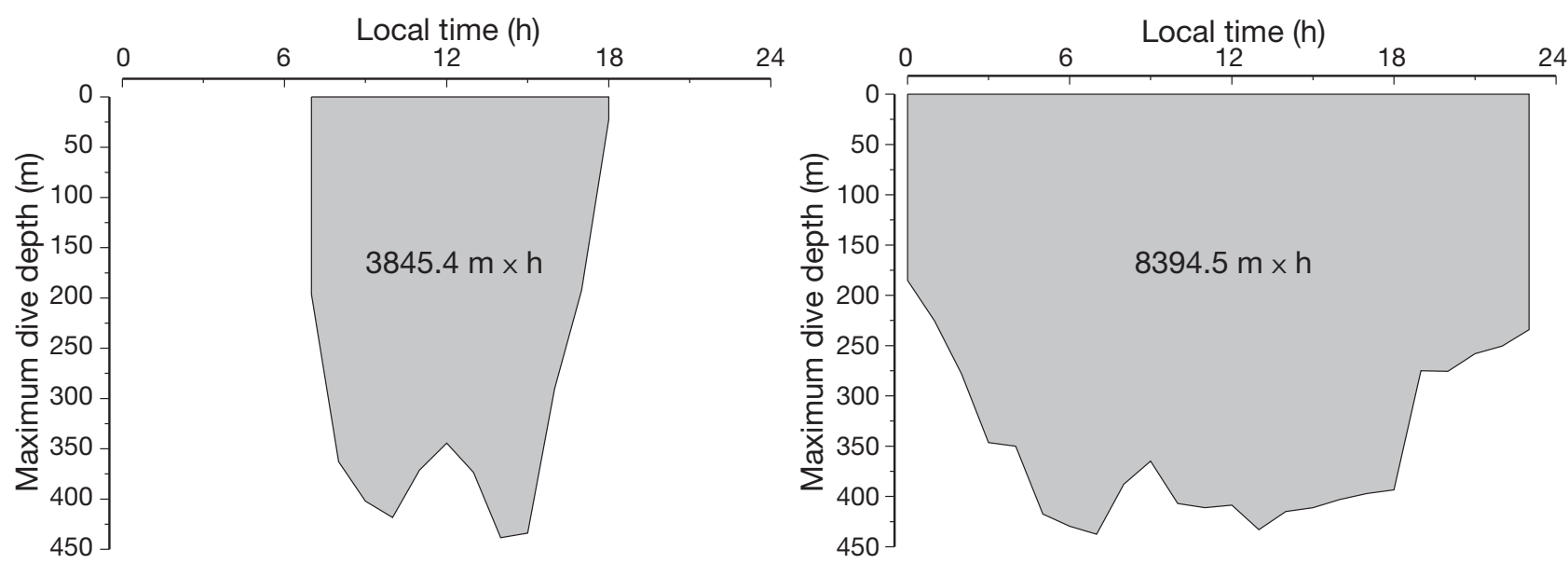

Fig. 5. Aptenodytes forsteri. Depth-time availability index (DTAI, $\mathrm{m} \times \mathrm{h}$ ) as a function of time of day of penguins at Pointe Géologie, Terre Adélie (see 'Results') in: (a) winter, between 22 May and 29 August ( $\mathrm{n}=5$ penguins; 19077 dives), and (b) spring, between 2 and 21 November 2005 ( $\mathrm{n}=4$ penguins; 5467 dives). The DTAI values (grey areas) are given in metre per hours ( $\mathrm{m} \times \mathrm{h})$ 


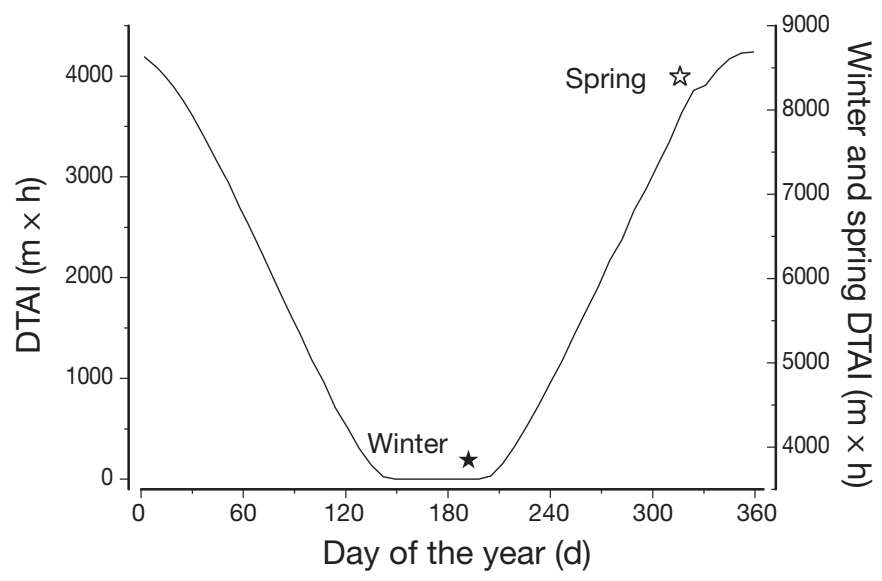

Fig. 6. Depth-time availability index (DTAI, $\mathrm{m} \times \mathrm{h}$ ) over a 1 yr cycle in 2005, derived by using an assumed critical light intensity of $30 \mathrm{~W} \mathrm{~m}^{-2}$, representing the lowest illumination at which prey can be perceived, at depth per hour over a day. Winter and spring marks (star symbols) stem from DTAI values from penguins (winter $n=5$; spring $n=4$ )

towards dawn and dusk (Fig. 7a). In contrast, mean CPUE during spring was highest when light levels were lowest. Average CPUE was highly related to the mean maximum diving depth in winter and spring $\left(\mathrm{r}^{2}=0.54, F=56.09, \mathrm{p}<0.0001 ; \mathrm{r}^{2}=0.43, F=67.43\right.$, $\mathrm{p}<0.0001$, respectively). CPUE was, however, negatively related to diving efficiency in winter $\left(\mathrm{r}^{2}=1.15\right.$, $F=7.89, \mathrm{p}<0.01)$, and positively, in spring $\left(\mathrm{r}^{2}=0.09\right.$, $F=8.57, \mathrm{p}<0.01)$.

\section{DISCUSSION}

Estimation of the availability of light as a function of depth down the water column is complex. Although calculation of the amount of total solar radiation impinging on the earth's atmosphere is relatively straightforward, being dependent on the latitude, day of the year and local time of day (Iqbal 1983), this light is then modulated by filters in the atmosphere such as cloud cover and particulate matter (Iqbal 1983). After reaching the sea surface, the angle of impingement (which depends on latitude, day of the year and time of day) then determines the angle at which the light continues down the water column, due to differences in the refractive index between air and water. Finally, for the light travelling down the water column, the degree of attenuation with depth depends on the extent to which water filters out different wavelengths (Kirk 1994) and the optical properties of the water, such as the presence of particulate matter, which varies with depth (Jerlov 1968). The degree of particulate matter varies with weather and biological processes, particularly primary production (Jerlov 1968, Kirk 1994).
Given these complexities, it would seem unwise to attempt to determine absolute values of light, but rather to use simplistic models to elucidate trends, as we have done. Actual measurement of light as a function of water depth is hardly less fraught with difficulty. Simple light transducers, such as the one we used on the penguins, respond in a general manner to the intensity of light energy, but do not react to all wavelengths equally and therefore give a biased view of light availability down the water column, which explains why the device manufacturers are imprecise in their specifications (see 'Materials and methods'). Proper assessment of light extinction with depth necessitates the use of complex instrumentation, which assesses absolute energy values for all the different wavelengths (Jerlov 1968, Kirk 1994). Ultimately though, even such onerous procedures are of limited value for penguins if the spectral sensitivity of the species is not known (e.g. Martin \& Young 1984, Martin 1999). Despite these misgivings, there are a number of general trends that we can discern from our approach.

Our data show that emperor penguins Aptenodytes forsteri have variabilities in their dive depths that accord with the generally supposed availability of light (Fig. 4), and our crude measures of light intensity with depth and sun angle (Fig. 3) lend weight to this. This strengthens findings by Kooyman \& Kooyman (1995), Kirkwood \& Robertson (1997a) and Wienecke \& Robertson (1997) for this species, and suggests that emperor penguins are typical of the Spheniscidae in being dependent on light to be able to forage (e.g. Cannell \& Cullen 1998: little penguins; Wilson et al. 1993: king, chinstrap, Adélie, gentoo and African penguins; Luna-Jorquera \& Culik 1999: Humboldt penguins; Peters et al. 1998: Magellanic penguins). This has profound implications for a species that lives so far south because of the massive changes in appropriate foraging conditions over the course of the year (Fig. 1), which modulate both the number of hours per day that can be spent foraging as well as the depths at which prey can be exploited (Figs. 6 \& 7). During summer, emperor penguins apparently may dive up to $200 \mathrm{~m}$ during the entire $24 \mathrm{~h}$ period, whereas during winter, foraging appears to be feasible for only a few hours (Fig. 4). Theoretically, winter-foraging birds may increase the amount of light they have for foraging by travelling north (cf. Ancel et al. 1992, Kirkwood \& Robertson 1997b, Wienecke \& Robertson 1997; our Fig. 8). The extended foraging trips of around 70 to $80 \mathrm{~d}$ undertaken by females during winter should allow them time to do this, although information on the areas exploited by females at this time shows that there is only limited movement north (Wienecke \& Robertson 1997, Zimmer et al. 2007b). The feasibility of movement north as a strategy will depend on energy 

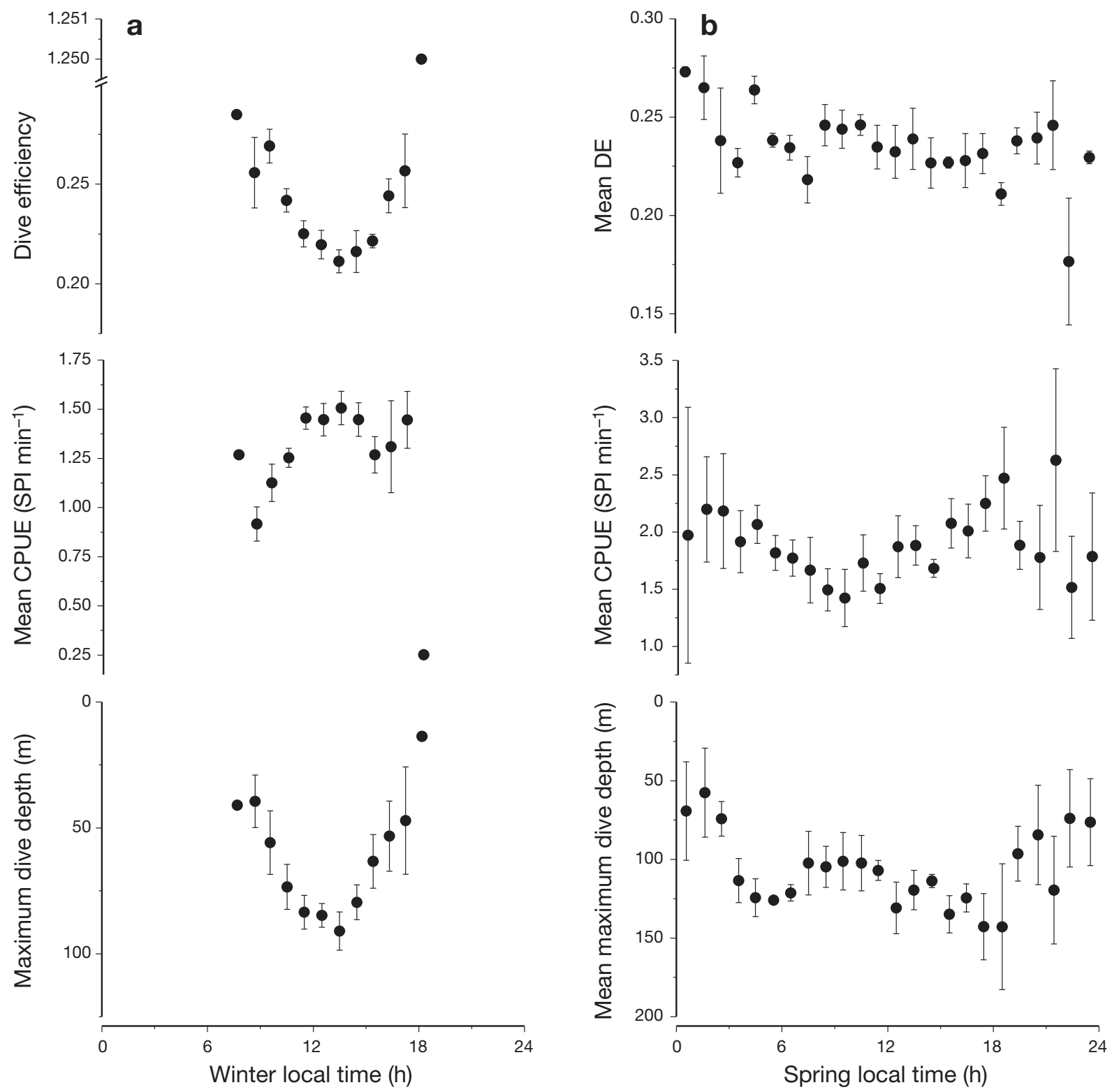

Fig. 7. Aptenodytes forsteri. Diurnal pattern of the foraging parameters, maximum dive depth, catch-per-unit-effort (CPUE, SPI $\left.\min ^{-1}\right)$ and dive efficiency (DE) of emperor penguins in: $(a)$ winter $(n=5)$ and $(b)$ spring $(n=4)$. Data are presented as grand mean values of penguin means per season and hour of the day ( $\pm 1 \mathrm{SE}$ ), calculated for all dives with post-dive intervals $<25$ min and the existence of a bottom phase (winter: $\mathrm{n}=14395$; spring: $\mathrm{n}=4853$ ). SPI:

and time invested travelling (and particularly the slow travel that involves walking over the ice), the real increase in time and depth available for foraging (Fig. 8) and the abundance of prey at sites farther north. The extent to which birds forage under ice, or in the proximity to ice (such as foraging in polynias or in ice fissures; see Ancel et al. 1992, Kirkwood \& Robertson 1997b, Rodary et al. 2000a) will greatly affect light conditions.

Systematic patterns in depth use according to hour of the day have been noted for a number of marine verte- brates: fish (e.g. Sims et al. 2005), reptiles (e.g. Eckert et al. 1988), mammals (e.g. Croxall et al. 1985) and birds (e.g. Wilson et al. 1993, Bost et al. 2002), with the normal pattern consisting of deeper dives at mid-day than at night. This has been attributed variously to predators needing light to perceive prey, and predators exploiting prey that conduct diel vertical migration, being nearer to the surface at night than during the day. The primary reason for prey movement up and down the water column is considered to relate to the exploitation of the productive surface waters at night 


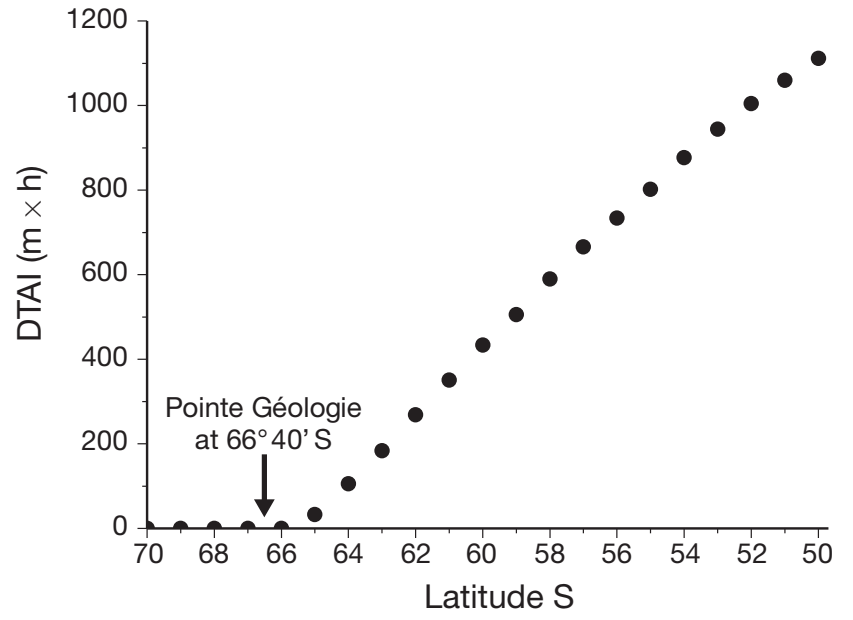

Fig. 8. Depth-time availability index (DTAI, $m \times h$ ) for emperor penguins at Pointe Géologie longitude $140^{\circ} 01^{\prime} \mathrm{E}$, Terre Adélie, calculated for latitudes between 70 and $50^{\circ} \mathrm{S}$. Example for day of the year 196, in winter

when visual predators have difficulty foraging (McLaren 1974, Kalinowski \& Witek 1980, Gliwicz 1986). Although the maximum depth boundaries over the course of the day identified in our study (Fig. 4) appear to represent absolute maxima beyond which emperor penguins cannot forage, the real issue is which depths are optimal. This will depend on the distribution of prey, given by the extent to which vertically migrating prey might be located within the penguins' limits, and the foraging efficiency of the penguins at that depth. Generally, increases in maximum dive depth result in decreases in efficiency (Zimmer et al. in press) because longer dives require longer recovery periods (e.g. Butler \& Jones 1997, Kooyman \& Ponganis 1998, Wilson \& Quintana 2004) so it is hardly surprising to find that penguins diving deeper as light levels increase also become less efficient (Fig. 7). This decrease in efficiency can be justified, however, if prey concentrations in deeper waters are high enough. Our data on CPUE indicate that the deep diving in winter at least is in accord with higher prey densities (Fig. 7a). During winter, emperor penguins feed predominantly on Antarctic krill Euphausia superba (Kirkwood \& Robertson 1997a,b), which is bentho-pelagic during the Antarctic winter and remains close to the seabed on the continental shelf (Kawaguchi et al. 1986, Taki et al. 2005); this may explain the deep diving effort with high CPUE of foraging penguins in winter. The situation is reversed during spring, however, when CPUE values are highest during periods when light intensity appears to be lowest on any given day (although still high enough to allow penguins to forage at depths of up to $200 \mathrm{~m}$; Fig. $7 \mathrm{~b}$ ). We postulate that at this time the normal diel vertical migration of prey has been resumed and that the higher CPUE during the darkest hours corresponds to penguins exploiting prey that are feeding nearer to the surface. In summer, the greatest densities of krill are found at 0 to $70 \mathrm{~m}$ depth (Siegel 1985, Higginbottom \& Hosie 1989, Godlewska 1993). Moreover, the nototheniid Pleuragramma antarcticum, probably the main fish prey of emperor penguins from Pointe Géologie (cf. Offredo \& Ridoux 1986, Cherel \& Kooyman 1998, Zimmer et al. 2007a), shows diurnal vertical migration (Plötz et al. 2001). In the Antarctic summer, however, this species is most abundant in the upper $150 \mathrm{~m}$ of the water column during the night (Mintenbeck et al. unpubl. data). We presume that emperor penguins in spring feed intensively on this prey, particularly since the energy density of nototheniids is higher than that of both krill and squid (cf. Zimmer et al. 2007a), and that this explains some of the pattern that we observed. This contrasts with what has been observed in other penguin species, where shallower dives at night correspond to the virtual cessation of feeding (Wilson et al. 1993). Indeed, based on this, such night dives have been interpreted as representing travelling behaviour (Wilson et al. 1993).

The ability of the emperor penguin to exploit prey throughout the diel cycle, therefore, appears to depend on the continuous light conditions during the summer and is enhanced by the exceptional water clarity in Antarctica (Jerlov 1968). It is this same clarity that lets greater light intensities down the water column at mid-day, making foraging technically feasible from a sensory perspective at depths in excess of $400 \mathrm{~m}$. Such depths exceed the physiological capacities of the smaller penguin species (Wilson 1995, Ponganis \& Kooyman 2000, Halsey et al. 2006). Indeed, where vertical movements of prey are extensive and the light penetration down the water column substantial, we expect a strong selection pressure for penguins to have a larger body mass. Thus, aside from the thermal advantages in Antarctic penguins having a larger body mass (Schmidt-Nielsen 1993, Ponganis \& Kooyman 2000), the particular conditions of variation in light and prey behaviour may play a role in modulating the body size of the largest living penguin species.

Acknowledgements. We thank G. König-Langlo from the Alfred Wegener Institute for Polar and Marine Research (AWI) for the processing of astronomic calculations. The Institut Polaire Français (IPEV) et Terres Australes et Antarctiques Françaises (TAAF) provided logistical support for the present study.

\section{LITERATURE CITED}

Ancel A, Kooyman GL, Ponganis PJ, Gendner JP and others (1992) Foraging behaviour of emperor penguins as a resource detector in winter and summer. Nature 360:336-339 
Bannasch R, Wilson RP, Culik B (1994) Hydrodynamic aspects of design and attachment of a back-mounted device in penguins. J Exp Biol 194:83-96

Bost CA, Zorn T, Le Maho Y, Duhamel G (2002) Feeding of diving predators and diel vertical migration of prey: king penguins' diet versus trawl sampling at Kerguelen Islands. Mar Ecol Prog Ser 227:51-61

Butler PJ, Jones DR (1997) Physiology of diving of birds and mammals. Physiol Rev 77:837-899

Cannell BL, Cullen ML (1998) The foraging behaviour of little penguins (Eudyptula minor) at different light levels. Ibis 140:467-471

Cherel Y, Kooyman GL (1998) Food of emperor penguins (Aptenodytes forsteri) in the western Ross Sea, Antarctica. Mar Biol 130:335-344

> Croxall J, Everson I, Kooyman GL, Ricketts C (1985) Fur seal diving behaviour in relation to vertical distribution of krill. J Anim Ecol 54:1-8

Eckert SA, Eckert KL, Ponganis PJ, Kooyman GL (1988) Diving and foraging behavior of leatherback sea turtles (Dermochelys coriacea). Can J Zool 67:2834-2840

Gentry RL, Kooyman GL (1986) Methods of dive analysis. In: Gentry RL, Kooyman GL (eds) Fur seals: maternal strategies on land and at sea. Princeton University Press, Princeton, NJ, p 28-40

Gliwicz MZ (1986) Predation and the evolution of vertical migration in zooplankton. Nature 320:746-748

Godlewska M (1993) Acoustic observations of krill (Euphausia superba) at the ice edge (between Elephant Island and South Orkney Island, December 1988/January 1989). Polar Biol 13:507-514

Halsey LG, Butler PJ, Blackburn TM (2006) A phylogenetic analysis of the allometry of diving. Am Nat 167:276-287

Higginbottom I, Hosie GW (1989) Biomass and population structure of a large aggregation of krill near Prydz Bay, Antarctica. Mar Ecol Prog Ser 58:197-203

Hull CL (2000) Comparative diving behaviour and segregation of the marine habitat by breeding royal penguins, Eudyptes schlegeli, and eastern rockhopper penguins, Eudyptes chrysocome filholi, at Macquarie Island. Can J Zool 78:333-345

Iqbal M (1983) An introduction to solar radiation. Academic Press, London

Jerlov NG (1968) Optical oceanography. Elsevier, Amsterdam

Kalinowski J, Witek Z (1980) Diurnal vertical distribution of krill aggregations in the western Antarctic. Pol Polar Res 1:127-146

Kawaguchi K, Ishikawa S, Matsuda O (1986) The overwintering strategy of Antarctic krill (Euphausia superba Dana) under the coastal fast ice off the Ongul Islands in LützowHolm Bay, Antarctica. Mem Natl Inst Polar Res (Tokyo) 44(Spec):67-85

Kirk JTO (1994) Light and photosynthesis in aquatic ecosystems. Cambridge University Press, Cambridge

Kirkwood R, Robertson G (1997a) Seasonal change in the foraging ecology of emperor penguins on the Mawson Coast, Antarctica. Mar Ecol Prog Ser 156:205-223

Kirkwood R, Robertson GG (1997b) The foraging ecology of female emperor penguins in winter. Ecol Monogr 67: 155-176

König-Langlo G, Loose B (2007) The meteorological observatory at Neumayer Station (GyN and NM-II) Antarctica. Polarforschung 76(1/2):25-38

> Kooyman GL, Kooyman TG (1995) Diving behavior of emperor penguins nurturing chicks at Coulman Island, Antarctica. Condor 97:536-549

Kooyman GL, Ponganis PJ (1998) The physiological basis of diving to depth: birds and mammals. Annu Rev Physiol 60: $19-32$

Luna-Jorquera G, Culik BM (1999) Diving behaviour of Humboldt penguins (Spheniscus humbolti) in northern Chile. Mar Ornithol 27:67-76

Martin GR (1999) Eye structure and foraging in king penguins Aptenodytes patagonicus. Ibis 141:444-450

Martin GR, Young SR (1984) The eye of the Humboldt penguin, Spheniscus humboldti: visual field and schematic optics. Proc R Soc Lond B Biol Sci 223:197-222

McLaren IA (1974) Demographic strategy of vertical migration by a marine copepod. Am Nat 108:91-102

Offredo C, Ridoux V (1986) The diet of emperor penguins Aptenodytes forsteri in Adélie Land, Antarctica. Ibis 128: 409-413

Peters G, Wilson RP, Scolaro JA, Laurenti S, Upton J, Galleli H (1998) The diving behavior of Magellanic penguins at Punta Norte, Península Valdés, Argentina. Colon Waterbirds $21: 1-10$

Plötz J, Bornemann H, Knust R, Schröder A, Bester M (2001) Foraging behaviour of Weddell seals, and its ecological implications. Polar Biol 24:901-909

Ponganis PJ, Kooyman GL (2000) Diving physiology of birds: a history of studies on polar species. Comp Biochem Physiol A 126:143-151

Pütz K, Bost CA (1994) Feeding behaviour of free-ranging king penguins (Aptenodytes patagonicus). Ecology 75:489-497

Pütz K, Wilson RP, Charrassin JB, Raclot T and others (1998) Foraging strategy of king penguins (Aptenodytes patagonicus) during summer at the Crozet Islands. Ecology 79 : 1905-1921

Rodary D, Bonneau W, Le Maho Y, Bost CA (2000a) Benthic diving in male emperor penguins Aptenodytes forsteri foraging in winter. Mar Ecol Prog Ser 207:171-181

Rodary D, Wienecke BC, Bost CA (2000b) Diving behaviour of Adélie penguins (Pygoscelis adéliae) at Dumont D'Urville, Antarctica: nocturnal patterns of diving and rapid adaptations to changes in sea-ice condition. Polar Biol 23:113-120

> Ropert-Coudert Y, Kato A, Wilson RP, Cannell B (2006) Foraging strategies and prey encounter rate of free-ranging little penguins. Mar Biol 149:139-148

Schmidt-Nielsen K (1993) Animal physiology: adaptation and environment. Cambridge University Press, Cambridge

Siegel V (1985) The distribution pattern of krill, Euphausia superba, west of the Antarctic Peninsula in February 1982. Meeresforschung 30:292-305

> Sims DW, Southall EJ, Tarling GA, Metcalfe JD (2005) Habitatspecific normal and reverse diel vertical migration in the plankton-feeding basking shark. J Anim Ecol 74:755-761

Sivak J, Howland HC, McGill-Harelstad P (1987) Vision of the Humboldt penguin (Spheniscus humboldti) in air and water. Proc R Soc Lond B Biol Sci 229:467-472

Takahashi A, Dunn MJ, Trathan PN, Croxall JP, Wilson RP, Sato K, Naito Y (2004) Krill-eating behaviour in a chinstrap penguin (Pygoscelis antarctica) compared with fisheating in Magellanic penguins (Spheniscus magellanicus): a pilot study. Mar Ornithol 32:7-54

Taki K, Hayashi T, Naganobu M (2005) Characteristics of seasonal variation in diurnal vertical migration and aggregation of Antarctic krill (Euphausia superba) in the Scotia Sea, using Japanese fishery data. CCAMLR Science 12: $163-172$

> Thode A, Mellinger DK, Stienessen S, Martinez A, Mullin K (2002) Depth-dependent acoustic features of diving sperm whales (Physeter macrocephalus) in the Gulf of Mexico. J Acoust Soc Am 112:308-321

Tremblay Y, Cherel Y (2000) Benthic and pelagic dives: a new 
foraging behaviour in rockhopper penguins. Mar Ecol Prog Ser 204:257-267

Vitousek MN, Rubenstein DR, Wikelski M (2007) The evolution of foraging behaviour in the Galápagos marine iguana: natural and sexual selection on body size drives ecological, morphological, and behavioral specialisation. In: Reilly SM, McBrayer LD, Miles DB (eds) Lizard ecology. Cambridge University Press, Cambridge, p 491-507

Wanless S, Finley SK, Harris MP, McCafferty FJ (1999) Effect of the diel light cycle on the diving behaviour of two bottom feeding marine birds: the blue-eyed shag Phalocrocorax atriceps and the European shag P. aristotelis. Mar Ecol Prog Ser 188:219-224

Wienecke BC, Robertson GG (1997) Foraging space of emperor penguins Aptenodytes forsteri in Antarctic shelf waters in winter. Mar Ecol Prog Ser 159:249-263

Williams TD (1995) The penguins. Bird families of the world. Oxford University Press, Oxford

Wilson RP (1995) Foraging ecology. In: Williams TD (ed) The penguins. Bird families of the world. Oxford University Press, Oxford, p 81-106

Wilson RP, Quintana F (2004) Surface pauses in relation to dive duration in imperial cormorants; how much time for a breather? J Exp Biol 207:1789-1796

Wilson RP, Culik B, Coria NR, Adelung D, Spairani HJ (1989) Foraging rhythms in Adélie penguins (Pygoscelis adeliae)

Editorial responsibility: Victor Benno Meyer-Rochow, Bremen, Germany at Hope Bay, Antarctica; determination and control. Polar Biol 10:161-165

Wilson RP, Pütz K, Bost CA, Culik BM, Bannasch R, Reins T, Adelung D (1993) Diel dive depth in penguins in relation to diel vertical migration of prey-whose dinner by candlelight? Mar Ecol Prog Ser 94:101-104

Wilson RP, Pütz K, Peters G, Culik B, Scolaro JA, Charrassin JB, Ropert-Coudert Y (1997) Long-term attachment of transmitting and recording devices to penguins and other seabirds. Wildl Soc Bull 25:101-106

Woehler EJ (1993) The distribution and abundance of Antarctic and subantarctic penguins. Scientific Committee on Antarctic Research, Cambridge

Ydenberg RC, Clark CW (1989) Aerobiosis and anaerobiosis during diving by western grebes: an optimal foraging approach. J Theor Biol 139:437-449

Zimmer I, Piatkowski U, Brey T (2007a) The trophic link between squid and the emperor penguin Aptenodytes forsteri at Pointe Géologie, Antarctica. Mar Biol 152: 1187-1195

Zimmer I, Wilson RP, Gilbert C, Beaulieu M, Ancel A, Plötz J (2007b) Foraging movements of emperor penguins at Pointe Géologie, Antarctica. Polar Biol 31:229-243

Zimmer I, Wilson RP, Beaulieu M, Ancel A, Plötz J (in press) Dive efficiency in relation to depth in foraging emperor penguins. Aquat Biol

Submitted: September 3, 2007; Accepted: July 8, 2008 Proofs received from author(s): August 8, 2008 